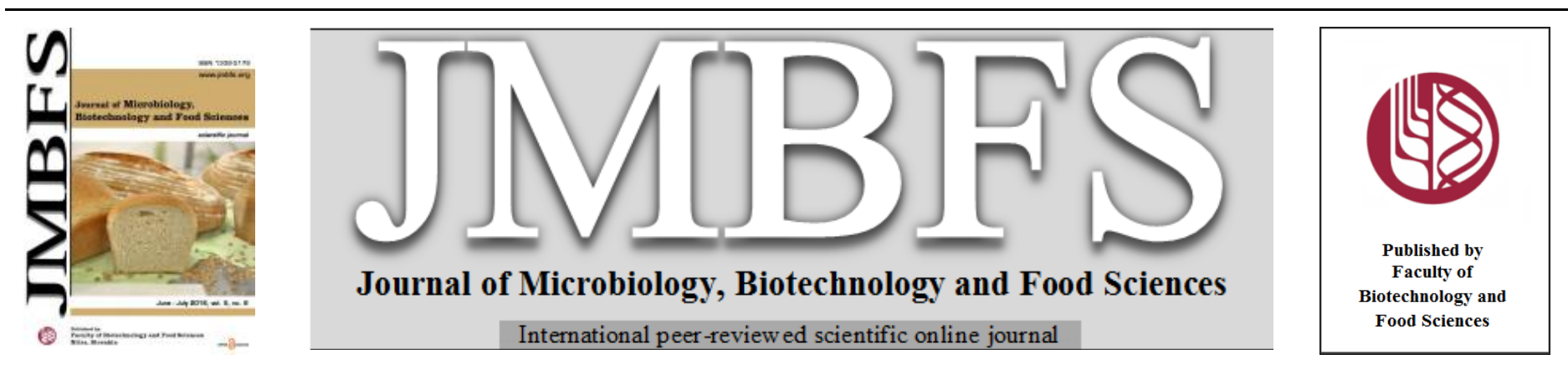

\title{
AGROCHEMICALS AFFECT THE ANTIOXIDATIVE DEFENSE POTENTIAL of COTTON PLANTS
}

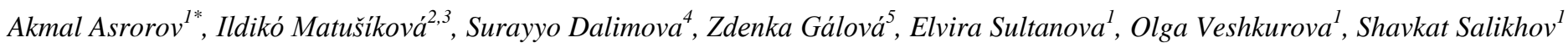

\begin{abstract}
$\operatorname{Address}(e s)$ :
${ }^{1}$ Department of Proteins and Peptides Chemistry, A.S.Sadykov Institute of Bioorganic Chemistry, Uzbek Academy of Sciences, M.Ulughbek 83, Tashkent, Uzbekistan. ${ }^{2}$ Department of Molecular Biology and Biotechnology, Institute of Plant Genetics and Biotechnology, Slovak Academy of Sciences, Akademicka 2, Nitra, Slovakia. ${ }^{3}$ Department of Ecochemistry and Radioecology, Faculty of Natural Sciences, University of SS. Cyril and Methodius in Trnava, Nám. J. Herdu 2, SK-917 01, Trnava, Slovakia.

${ }^{4}$ Department of Biology and Soil Sciences, National University of Uzbekistan, Talabalar shaharchasi, Tashkent, Uzbekistan.

${ }^{5}$ Department of Biochemistry and Biotechnology, Slovak University of Agriculture, Tr. Andreja Hlinku 2, 94976 Nitra, Slovakia.

*Corresponding author: akmal84a@gmail.com

doi: 10.15414/jmbfs.2016.5.6.505-508

ARTICLE INFO

Received 20. 5. 2015

Revised 25. 8. 2015

Accepted 13. 1.2016

Published 1. 6. 2016

Regular article

open $\partial_{\text {ACCESS }}$

\section{ABSTRACT}

Application of insecticides used in cotton fields is often associated with secondary biotic stresses. One of possible reasons of such phenomenon is explained by decreased contents of plants' defense components. As peroxidase (POD) and polyphenoloxidase (PPO) are typical oxidoreductase enzymes scavenging cell oxidative damage, we studied their change levels in cotton leaves in response to the application of three insecticides field experiment. Moreover, the concentration of proline (Pro), methionine (Met) and cysteine (Cys) was studied. The plants were treated with Carbophos, Lannate and Sumi-alfa in early blooming stage at commonly used doses in. Leaf samples were taken on the $10^{\text {th }}$ and $13^{\text {th }}$ days of the treatment. A pyrethroid insecticide Sumi-alfa appeared to negatively impact activities of both POD and PPO $(P \leq 0.05)$, contrasting the other two insecticides examined. On the other hand, levels of amino acids with antioxidative properties increased after application of all three insecticides at the end of experiment. Our results show that the oxidative balance of treated plants was interrupted by insecticides (especially Sumi-alfa) with potential impact on vulnerability to secondary stresses. Effects of these insecticides on cotton should be considered and/or studied in more detail for efficient application in agriculture.
\end{abstract}

Keywords: Cotton plant, Insecticides, Peroxidase, Polyphenoloxidase, Proline, Methionine, Cysteine

\section{INTRODUCTION}

Application of insecticides is often reported to be associated with secondary biotic stress. For example increased number of aphids in cotton fields, treated with pyrethroid $\lambda$-cyhalothrin against bollworm, has been observed (Kerns and Gaylor, 1993; Leser, 1994; Ravindhran and Xavier, 1997; Asrorov et al. 2014). Further, rapid increase in aphid populations after sulprofos and cypermethrin was determined that is unlikely due to direct stimulation of aphid reproduction (Kerns and Gaylor, 1993). Rapid increases in aphid numbers were associated also with applications of the pyrethroid insecticides cypermethrin, and deltamethrin (Ravindhran and Xavier, 1997). Similar observations have been made for different agrochemicals applied on rice (Wu et al. 2001). It has been suggested that some agrochemicals might alter the biochemistry of the treated plants (Leroy et al. 2011) and/or might disrupt the oxidative balance of cells leading to weakening of plant defense. The latter is under normal physiological conditions crucial for optimal functioning of biological processes and in plants is controlled by various antioxidative compounds (e.g. ascorbic acid, glutathione) (Noori, 2012) and/or by induction of antioxidative enzymes such as peroxidases, catalases or dismutases (Zhang and Kirkham, 1994).

Interruption of oxidative balance results in accumulation of toxic reactive oxygenous species resulting in so called oxidative stress that can seriously injure the tissues. Several pesticides have previously been shown to alter the oxidative balance of cells in mammals and cause cell damages. To these pesticides belong an organochlorine insecticide dieldrin (Bachowski et al. 1998), the pyrethroid insecticides Deltametrin (El-Gohary $\boldsymbol{e t}$ al. 1999) and cypermethrin (Kale $\boldsymbol{e t}$ al. 1999). In plants pyrethroid insecticides were found to decrease catalase and phenylalanine ammonia lyase activities, and total ascorbate and cinnamic acid concentrations in tissues (Ravindhran and Xavier, 1997; Bashir et al. 2007) On the other hand, some agrochemical have been suggested as potential plant immunization agents inducing systemic acquired resistance (SAR) in plants, leading to broad-based, long-lasting resistance to a wide range of pathogens (Enyong Arrey Besong, 2008).

The present work was undertaken to study the effect of selected agrochemicals on oxidative balance in cotton plants that might be indicative for explaining the plant vulnerability to secondary stresses. As compounds of antioxidative defense systems we monitored the activity of antioxidative enzymes as well as accumulation of certain amino acids. Of these, peroxidase (POD) was found to have a defense role in eliminating oxidative burst in cotton upon abiotic stress (Akhunov et al. 1999) and also attack of bacterial blight (Delannoy et al. 2003), the phytopathogen Verticillium dahliae (Pshenichnov et al. 2011) and herbivore feeding (Stout $\boldsymbol{e}$ al a 1998). POD activity was often found greater in resistant variety than in susceptible (Akhunov et al. 2010). On the other hand, polyphenoloxidase (PPO) has been shown to act upon attack of bacterial pathogen Pseudomonas syringae $p v$. (Li and Steffens, 2002) and arthropod herbivores (Felton et al. 1989), common cutworm Spodoptera litura F., cotton bollworm Helicoverpa armigera (Hubner) and beet army worm Spodoptera exigua (Hubner) (Thipyapong et al. 2007). Several previous investigations showed that the activities of these enzymes were affected after application of insecticide imidacloprid at recommended concentration ( $40 \mathrm{ml} / \mathrm{acre}$ ) in three $\mathrm{Bt}$ cotton hybrids (RCH-134, JKCH-1947, NCEH-6R) (Kaur et al. 2011) and potato plants (Chauhan et al. 2013).

Agrochemicals can also affect nitrogen metabolism (Slosser et al. 2004) including accumulation of proline (Pro), methionine (Met) and cysteine (Cys) with importance in plant defense. The free Pro has multifunctional role in plant immunity and development, while it is induced by reactive oxygen species signalling (Ben Rejeb et al. 2014). Pro is also known to indirectly enhance plant antioxidant defense system (Hoque et al., 2007; Ozden et al. 2009). The sulphur containing amino acid Cys plays an important role as an extracellular reducing agent (Atmaca 2004). It is a central metabolite serving as a sulphur donor for the synthesis of Met (Zagorchev $\boldsymbol{e t}$ al. 2013), which is an efficient scavenger of almost all oxidizing molecules under physiological condition, such as, hydrogen peroxidase, hydroxyl radicals (Levin $\boldsymbol{e t}$ al. 1996). Under water deficit in cotton plant leaves Met concentration fluctuated widely (Marur $\boldsymbol{e t}$ al. 1994). Under the effects of cypermethrin Met concentration increased in both organophosphorus insecticide resistant and susceptible plant varieties (Saleem and Shakoori, 1993). 
We studied the impact of three agrochemicals organophosphate Carbophos, pyrethroid Sumi-alfa and carbamate Lannate on antioxidative defense components in cotton plants. All three chemicals are being widely used in Uzbekistan for treatment against pests, but their possible (negative) impact on treated plant antioxidative system has not been studied in detail.

\section{MATERIAL AND METHODS}

\section{Experimental Design}

Field experiments were conducted on cotton variety S 26 (G. hirsutum) growing at the pre-bloom stage in the cotton field of the Institute for Plant Protection of the Ministry of Agriculture and Water Resources of Uzbekistan (Tashkent Region, Kibray District, Salar Township). The concentration of each insecticide was prepared according to the consumption norm recommended by producers against cotton pests (Table 1). The solutions were sprayed once in the early morning at 6:00 to 6:30AM. Treatment of plants with three insecticides was a randomized block with 4 replications. Sixteen plants were treated by each insecticide and water was used as control (a total of 4 treatments). The solutions were sprayed once in early morning. A total of 14-16 different developed stages of leaves were taken from the upper, middle, and lower parts of 60-65 plants on the $10^{\text {th }}$ and $13^{\text {th }}$ days after treatment that our former results showed the highest changes in the quantity of soluble proteins and sugars were observed on these days (Asrorov et al. 2014). They were averaged and lyophilized. During the experiments no effect of insects in the treated fields was observed.

Table 1 Treatment, chemical class and application rates

\begin{tabular}{lcc}
\hline Treatment & Class & $\begin{array}{c}\text { Application } \\
\text { rate 1/ha }\end{array}$ \\
\hline Control & & Water \\
Carbophos, Aerosoyuz, Russia & Organophosphate & 0,6 \\
Lannate, Du-Pont, France & Carbamate & 0,25 \\
Sumi-alfa, Sumimoto chemical, Japan & Pyrethroid & 0,5 \\
\hline
\end{tabular}

\section{Protein Extractions and Analysis}

Lyophilized cotton leaves were ground with liquid nitrogen using a mortar and pestle. After grinding, the proteins of control and treated leaves were extracted with Tris-HCl buffer $(0.5$ M Tris-HCl pH 6.8, 20 mM EDTA, 2 mM PMSF, $1 \%$ Triton X-100, and $150 \mathrm{mM}$ DTT) for two hours with stirring. The mixture was filtered and in supernatant proteins were precipitated with cold absolute acetone $(1: 4 \mathrm{v} / \mathrm{v})$ and centrifuged $30 \mathrm{~min}\left(8000 \mathrm{r} / \mathrm{min}\right.$, at $\left.4^{\circ} \mathrm{C}\right)$. The residue was dissolved in water and freeze-dried. The quantity of soluble proteins was determined according to Lowry et al. (1951). For calibration, albumin bovine (from bovine serum; Sigma A7030) in appropriate amounts was weighed and dissolved in $\mathrm{Na}_{2} \mathrm{HPO}_{4}$ buffer $\mathrm{pH} 7$ to provide concentrations of $10-100 \mu \mathrm{g} / \mathrm{ml}$.

\section{POD Assay}

The total POD activity of the proteins isolated was determined using benzidine as the chromogenic substrate. Thus, $1.9 \mathrm{ml} 0.1 \mathrm{M} \mathrm{pH} 4.7$ acetate buffer $(11.5 \mathrm{ml}$ glacial acetic acid $+27.25 \mathrm{~g}$ sodium acetate and the volume was adjusted to 1000 $\mathrm{ml}$ ) was placed in a test tube, and $50 \mu \mathrm{l}$ of benzidine ( $40 \mu \mathrm{g}$ benzidine dissolved in $25 \mathrm{ml} 70 \%$ ethanol) was added. The solution was stirred thoroughly then 100 $\mu 1$ of protein solution (containing the enzyme) was added. After the addition of 50 $\mu l$ of hydrogen peroxide and $30 \mathrm{sec}$ passed, the optical density of the solution was measured at $620 \mathrm{~nm}$.

\section{PPO Assay}

Total PPO activity of proteins was studied using pyrogallol as a chromogenic substrate. Thus, to $2 \mathrm{ml}$ of phosphate buffer $\mathrm{pH} 8$, having protein solutions $(61 \mathrm{~g}$ $\mathrm{Na}_{2} \mathrm{HPO}_{4} \mathrm{H}_{2} \mathrm{O}$ and $39 \mathrm{~g} \mathrm{NaH}_{2} \mathrm{PO}_{4} \mathrm{H}_{2} \mathrm{O}$ were dissolved in $200 \mathrm{ml}$ of water) was added $50 \mu 10.15 \mathrm{M}$ substrate solution. The intensity of colored solution was determined at $460 \mathrm{~nm}$.

\section{Extraction of amino acids and their modification}

Dried samples of treated and control leaves were ground and pooled in liquid nitrogen. $200 \mathrm{mg}$ of each sample was weighed and extracted in $5 \mathrm{ml}$ of wateracetonitrile (9:1) for 15 minutes with homogenizer. The supernatant was isolated after centrifugation for 10 minutes (3000 rpm). Higher molecular compounds were precipitated adding 10\% trichloroacetic acid (1:1) for 15 minutes $(8000$ rpm). $200 \mu \mathrm{l}$ aliquot was taken and lyophilized. Dry extract was dissolved in 200 $\mu$ l water-acetonitrile-triethylamine $(1: 7: 1)$ then the extract was dried. The process was twice repeated. In order to obtain phenylthiocarbamoyl (PTC) derivatives purified samples and standard amino acid were modified with water -acetonitrilethriethylamine + phenylisotiocyonate $(1: 7: 1: 1)$ for 30 minutes.

\section{HPLC analysis}

Quantity analyses of PTC derivatives were conducted in Agilent technologies 1200 (Column: Supelco Discovery HS C18, Cat 56925/-U $7.5 \mathrm{~cm}$ x 4.6 mm, 3 $\mu \mathrm{m}$ ), with buffer: $\mathrm{B}-0.14 \mathrm{M} \mathrm{CH}_{3} \mathrm{COONa}+0.05 \%$ tetraethyl ammonium, $\mathrm{pH}$ 6.4, $\mathrm{A}-\mathrm{MeCN}$, gradient $\% \mathrm{~B} / \mathrm{min}, 0-6 \%, 5 \mathrm{~min}, 6-30 \%, 30 \mathrm{~min}, 30-60 \% 5$ $\min , 60-100 \% 5 \mathrm{~min}$. Amino acid derivatives were detected with a flow rate 1.2 $\mathrm{ml} / \mathrm{min}$ at $269 \mathrm{~nm}$.

\section{RESULTS AND DISCUSSION}

The three agrochemicals were once applied on cotton plants for 2 different time periods at doses commonly used in agriculture. Their sound effect on plant metabolism was obvious from data of protein yields isolated from the experimental plants. Sumi-alfa enhanced protein synthesis at both time periods (Fig. 1A). Similar effects were observed for imidacloprid on Bt cotton total protein (Kaur et al. 2011). In contrast Carbophos revealed an opposite (negative) effect $(P \leq 0.05)$ (Fig. $1 \mathrm{~A})$. Effects of Lannate were significant after 10 days but disappeared at later time (Fig. 1A).

The agrochemicals influenced the activity of antioxidative enzymes investigated. Sumi-alfa significantly inhibited the activity of both POD as well as PPO, after both application times (Fig. $1 \mathrm{~B}, \mathrm{C}$ ). The other two insecticides, in contrast, evoked a multiple increase of PPO activity at both sampling points (Fig. $1 \mathrm{~B}, \mathrm{C}$ ). Their effect on POD, however, was ambiguous since slight decrease $(P \leq 0.05)$ after 13 days was only observed for Carbophos and contrasting, time-dependent activity was measured for Lannate (Fig. 1B, C). Previously, imidacloprid insecticide at recommended concentration $(40 . \mathrm{ml} / \mathrm{acre})$ caused increased POD activity in three Bt cotton hybrids (RCH-134, JKCH-1947, NCEH-6R) (Kaur et al. 2011). Moreover, imidacloprid increased the activities of catalase, POD, PPO and the quantity of total protein in potato plants (Chauhan et al. 2013). Increased POD activities in imidacloprid applied plants partly coincide with the effects of carbamate lannate and enhanced PPO activity matches with the effects of lannate and carbophos. Decreased POD and PPO activities in Sumi-alfa applied leaves do not correspond with increased levels of POD and PPO activities under treatment of deltamethrin, cypermethrin and fenvalerate either (Ravindhran and Xavier, 1997).

Fluctuating changes were observed with Pro. After treatment with Lannate and Sumi-alfa lower than the control enzyme activities were found in samples taken on $10^{\text {th }}$ day after spray. However, later-on they caused higher enzyme activities than control. Twice higher Pro quantity was calculated after carbamate Lannate. Insignificant slight increases on the $10^{\text {th }}$ day samples and significant increases were studied on $13^{\text {th }}$ day samples after treatment with carbophos $(P \leq 0.05)$ (Fig. 1 D). Similar changes were observed with sulphur containing amino acids in all treated samples. All three chemicals significantly increased the quantity of Met and Cys (Fig E, F) $(P \leq 0.05)$. The highest increase was observed with samples treated with Carbophos that almost twice higher quantity of Met was gathered $\left(10^{\text {th }}\right.$ day) and mildest effects belonged to Sumi-alfa. $(P \leq 0.05)$ (Fig. $\left.1 \mathrm{E}\right)$ Samples treated with Carbophos on the $10^{\text {th }}$ day contained more Met and Cys than samples taken three days later, whereas, in comparison to control, linear increases were observed with Met and Cys after Lannate and Sumi-alfa treatment. The increased levels of Met in all treated samples match with the effects sulprofos on total essential amino acids (Kerns and Gaylor, 1993).

\section{CONCLUSION}

Our results show that application of the tested agrochemicals affects cotton plan antioxidative homeostasis that in turn is likely to have impact on defense potential. Among studied three insecticides pyrethroid sumi-alfa was found to negatively affect the activity of both enzymes. On the other hand, application of the tested insecticides evoked the accumulation of amino acids involved in antioxidative (and perhaps other) defense. Nevertheless, impact of these insecticides on defense potential of cotton should be considered and/or studied in more detail for efficient application in agriculture. 


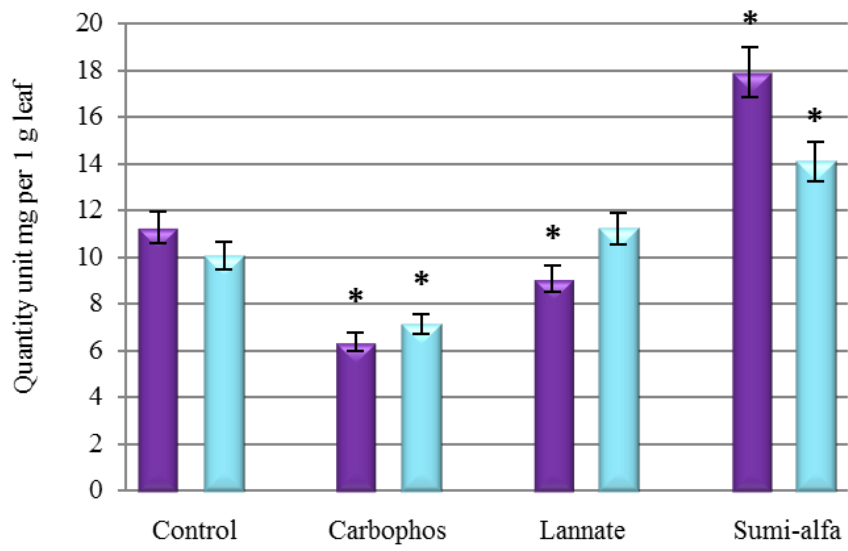

A

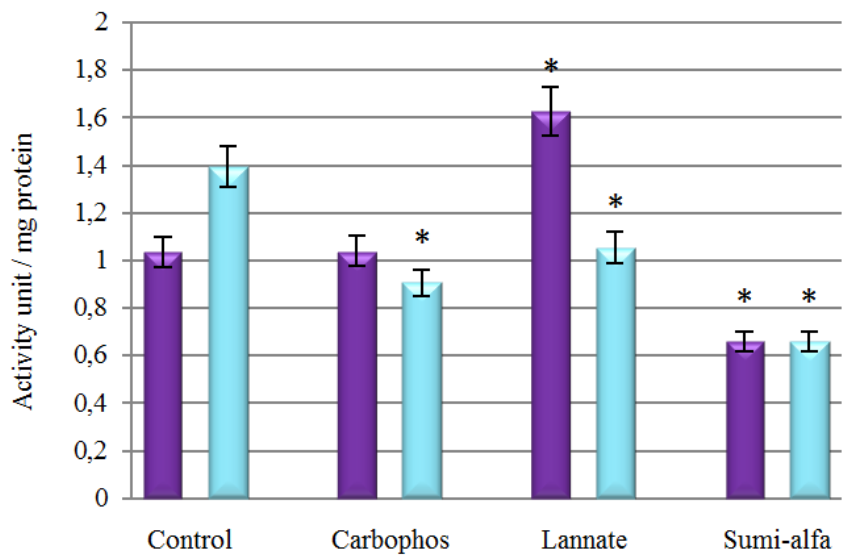

B

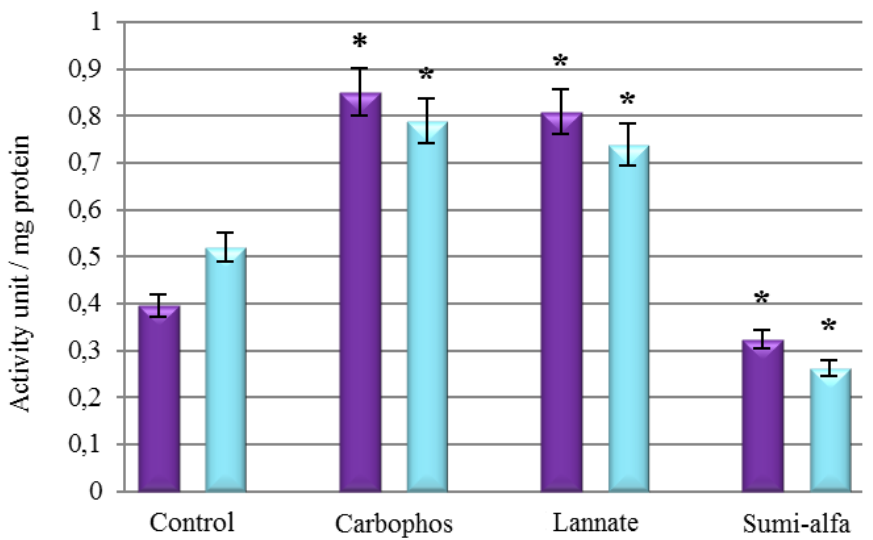

$\mathrm{C}$

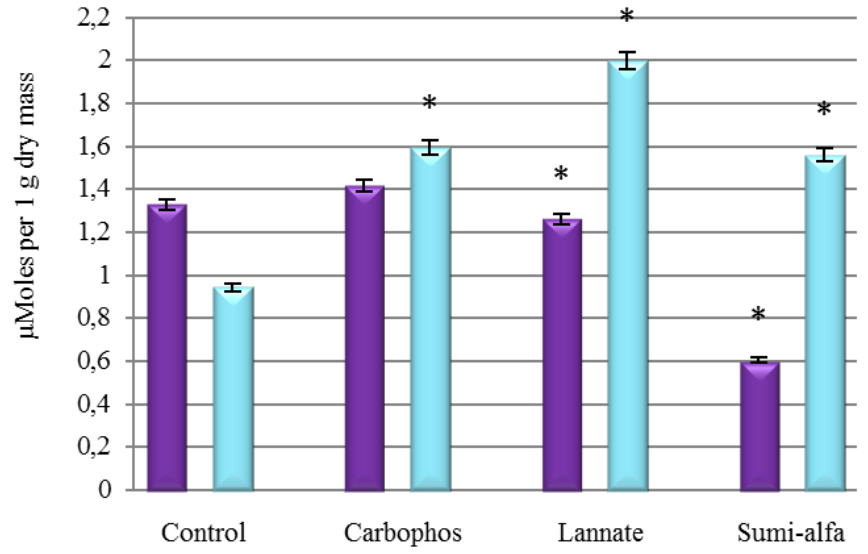

D
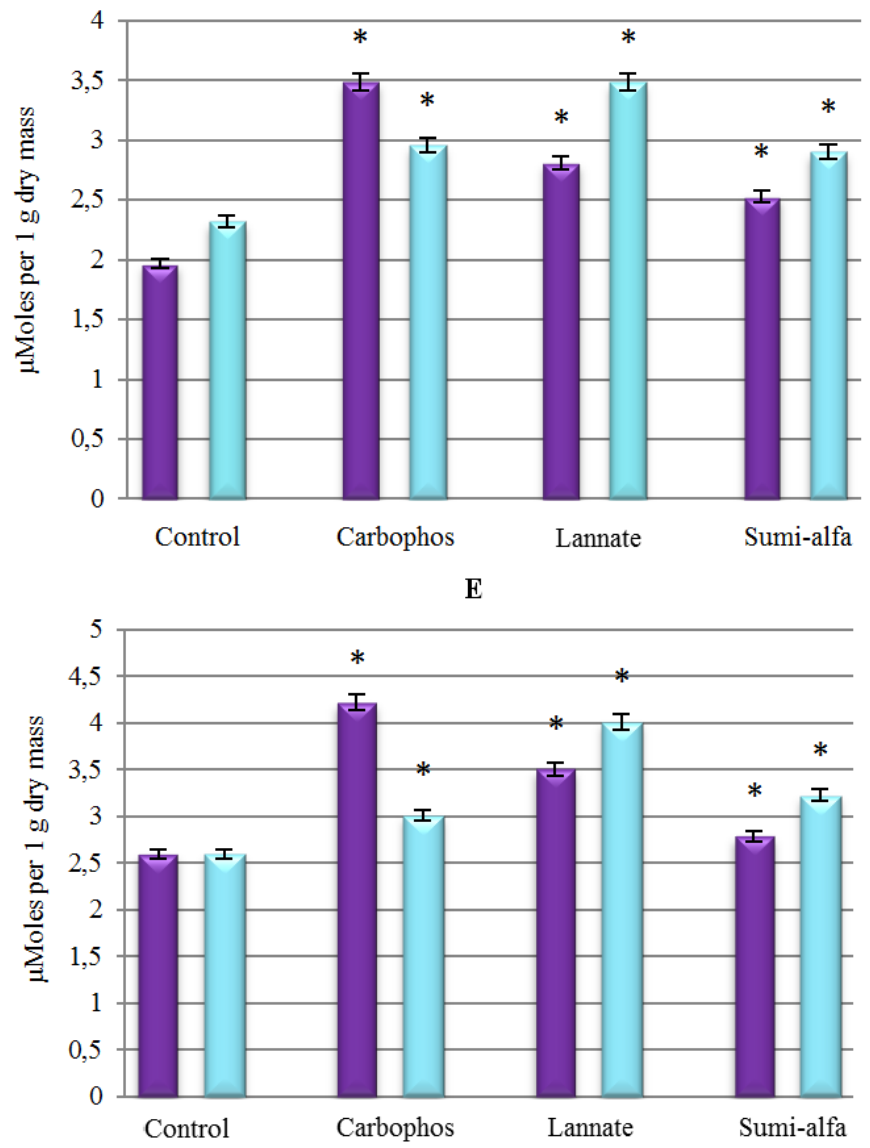

F

Figure 1 Changes in cotton leaves: A - Soluble proteins; B - POD activity; $\mathbf{C}-$ PPO activity; D - Pro content; $\mathbf{E}-$ Met content; $\mathbf{F}-\mathrm{Cys}$ content. Leaves taken for the analysis were statistically different. The SE is less than $2 \%$, data represent \pm SEM $(\mathrm{m} 3)$. Dark colours represent the $10^{\text {th }}$ day and light colors represent the $13^{\text {th }}$ day that samples taken after insecticides spray

\begin{abstract}
Acknowledgments: The Work was supported by CASIA (Central Asia Student International Academic exchange with EU, CASIA II, cohort III) project of European Union Erasmus Mundus Programme. The authors express their sincere thanks to Dr. Loreta Schwarczova, programme coordinator in Slovak University of Agriculture in Nitra, Dr. Mashkura Fakhrutdinova, coordinator of the programme in National University of Uzbekistan, Dr. Alim Pulatov, regional coordinator of the programme (Tashkent Institute of Irrigation and Melioration, Uzbekistan) and Dr. Ewa Wietsma, main coordinator of the programme (Wageningen Univerty, Holland) for the financial support with CASIA Programme.

Zdenka Gálová contributed by European Community project: Development of International Cooperation for the Purpose of the Transfer and Implementation of Research and Development in Educational Programs conducted by the Operational Program: Education,

ITMS code: 26110230085
\end{abstract}

\section{REFERENCES}

AKHUNOV, A.A., GOLUBENKO, Z., ABDURASHIDOVA, N.A., MUSTAKIMOVA, E.Ch., IBRAGIMOV, F.A., BERESNEVA, Yu.V. 1999. Effect of bentonite clay on biosynthesis of cotton cellulose. Chemistry of Natural Compounds, 35(6), 671-675.

http://dx.doi.org/10.1007/BF02236301

AKHUNOV, A.A., GOLUBENKO, Z., MUSTAKIMOVA, E.C., VSHIVKOV, S.O., MUKHAMEDKHANOVA, F.S. 2010. Activation mechanism of intra-and extracellular cotton PODs by wilt infection. Chemistry of Natural Compounds, 46(4), 608-611.

http://dx.doi.org/10.1007/s10600-010-9687-1

ASROROV, A.M., AISA, H.A., Yili, A., LING, M.Q., VESHKUROVA, O., SULTANOVA, E., SALIKHOV, Sh. 2014. Composite insecticides effects on defensive and nutritious compounds in cotton leaves. Journal of Plant Biochemistry \& Physiology, 2(1), 2-5

http://dx.doi.org/10.4172/2329-9029.1000122 
ATMACA, G., 2004. Antioxidant effects of sulfur-containing amino acids. Yonsei Medical Journal, 45: 776-788.

http://dx.doi.org/10.3349/ymj.2004.45.5.776

BACHOWSKI, S., XU, Y., STEVENSON, D.E., WALBORG, Jr.E.F., KLAUNIG, J.E. 1998. Role of oxidative stress in the selective toxicity of dieldrin in the mouse liver. Toxicology and Applied Pharmacology, 150, 301-309.

BASHIR, F., MAHMOODUZZAFAR, SIDDIQI, T.O., Muhammad, I. 2007. The antioxidative response system in Glycine max (L.) Merr. Exposed to Deltamethrin, a synthetic pyrethroid insecticide. Environmental Pollution, 147, 94-100.

http://dx.doi.org/10.1016/j.envpol.2006.08.013

BEN REJEB, K, ABDELLY, Ch., SAVOURE, A. 2014. How reactive oxygen species and proline face stress together. Plant Physiology and Biochemistry, 80, 278-284.

http://dx.doi.org/10.1016/j.plaphy.2014.04.007

CHAUHAN, S.S., AGRAWAL, S., SRIVASTAVA, A. 2013. Effect of imidacloprid insecticide residue on biochemical parameters in potatoes and its estimation by HPLC. Asian Journal of Pharmaceutical and Clinical Research, 6(3), 114-117.

DELANNOY, E., JALLOUL, A., ASSIGBETSE, K., MARMEY, P., GEIGER, J.P., LHERMINIER, J., DANIEL, J.F., MARTINEZ, C., NICOLE, M. 2003. Activity of Class III PODs in the Defense of Cotton to Bacterial Blight Molecular Plant-Microbe Interactions, 11, 1030-1038.

EL-GOHARY, M., AWARA, W.M., NASSAR, S., HAVAS, S. 1999 Deltamethrin-induced testicular apoptosis in rats: the protective effect nitric oxide synthase inhibitor. Toxicology, 132, 1-8.

http://dx.doi.org/10.1016/S0300-483X(98)00114-0

ENYONG, A.B. 2008. "Synthesis of Novel Agrochemicals as Potential Plan Immunization Agents." Electronic Theses and Dissertations Paper 1959 http://dc.etsu.edu/etd/1959.

FELTON, G.W., DONATO, K.K., DEL VECCHIO, R.J., DUFFEY, S.S. 1989 Activation of Plant Foliar Oxidases by Insect Feeding Reduces Nutritive Quality of Foliage for Noctuid Herbivores. Journal of Chemical Ecology, 15, 2667-2694. http://dx.doi.org/10.1007/BF01014725

HOQUE, M.A., BANU, M.N., NAKAMURA, Y., SHIMOISHI, Y., MURATA, Y. 2007. Exogenous proline mitigates the detrimental effects of salt stress more than the betaine by increasing antioxidant enzyme activities. Journal of Plant Physiology, 164, 553-561.

http://dx.doi.org/10.1016/J.JPLPH.2006.10.004

KALE, M., RATHORE, N., JOHN, S., BHATNAGAR, D. 1999. Lipid peroxidative damage on pyrethroid exposure and alterations in antioxidant status in rat eryththrocytes: a possible involvement of oxygen species, Toxicology Letters, 105: 197-205.

http://dx.doi.org/10.1016/S0378-4274(98)00399-3

KAUR, N., SOHAL, B.S., SINGH, K. 2011. Biochemical and physiological changes on Bacillus thuringiensis cotton after imidacloprid foliar spray. Pesticide Biochemistry and Physiology, 99(3), 280-284.

http://dx.doi.org/10.1016/j.pestbp.2011.01.007

KERNS, D.L., GAYLOR, M.J. 1993. Induction of cotton aphid outbreaks by insecticides in cotton. Crop Protection. 12, 387-393.

http://dx.doi.org/10.1016/0261-2194(93)90083-U

LEROY, P.D., WATHELET, B., SABRI, A., FRANCIS, F., VERHEGGEN, F.J. CAPELlA, Q., THONART, Ph., HAUBRUGE, E. 2011. Aphid-host plant interactions: does aphid honeydew exactly reflect the host plant amino acid composition?. Arthropod-Plant Interactions, 5, 1-7.

http://dx.doi.org/10.1007/s11829-011-9128-5

LESER, J.F. 1994. Management of cotton aphids: Texas style. In Proceedings, Beltwide Cotton Conference, National Cotton Council, Memphis, TN. 137-141.

LEVIN, R.L., Mosoni, L., Bertlett, B.S., Stadman, E.R. 1996. Methionine residues as endogenous antioxidants in proteins, Proc Natl. Acad. Sci USA, 15036-15040.

LI, L., STEFFENS, J.C. 2002. Overexpression of Polyphenol Oxidase in Transgenic Tomato Plants Results in Enhanced Bacterial Disease Resistance. Planta, 215, 239-247.

http://dx.doi.org/10.1007/s00425-002-0750-4

LOWRY, O.H., ROSENBROUGH, N.J., FARR, A.R., RANDAL, R.J. 1951.

Protein measurements with folin-phenol reagent. Journal of Biological

Chemistry, 193, 265-273.

MARUR, C.J., SODEK, L., MAGALHAES, C. 1994. Free amino acids in leaves of cotton plants under water deficit. Revista Brasileira de Fisiologia Vegetal, 2,103-108

NOORI, Sh. 2012. An Overview of Oxidative Stress and Antioxidant Defensive System. Open Access Scientific Reports, 1(8), 1-9.

OZDEN, M., DEMIREL, U., KAHRAMAN, A. 2009. Effects of proline on antioxidant system in leaves of grapevine (Vitis vinifera L.) exposed to oxidative stress by $\mathrm{H}_{2} \mathrm{O}_{2}$. Scientia horticulturae, $119,163-168$.

http://dx.doi.org/10.1016/j.scienta.2008.07.031

PSHENICHNOV, E., KHASHIMOVA, N., AKHUNOV, A.A., GOLUBENKO, Z., STIPANOVIC R.D. 2011. Participation of Chitin-Binding POD Isoforms in the Wilt Pathogenesis of Cotton. American Journal of Plant Sciences, 2, 43-49. http://dx.doi.org/10.4236/ajps.2011.21005

Ravindhran, R, Xavier, A. 1997. Effect of pyrethroids on resurgence of aphids (Aphis gossypii G.) and alteration of plant metabolism in cotton. Pesticide Research Journal, 19, 79-85.

SALEEM, M.A., SHAKOORI, AR. 1993. Effect of cypermethrin on free amino acid pool in an organophosphorus insecticide-resistant and susceptible strain of Tribolium castaneum, Comparative Biochemistry and Physiology C, 105, 549553.

http://dx.doi.org/10.1016/0742-8413(93)90100-Y

SLOSSER, J.E., PARAJULEE, M.N., HENDRIX, D.L., HENNEBERRY, T.J., PINCHAK, W.E. 2004. Cotton Aphid (Homoptera: Aphididae) Abundance in Relation to Cotton Leaf Sugars. Environmental Entomology, 33, 690-699.

http://dx.doi.org/10.1603/0046-225X-33.3.690

STOUT, M.J., WORKMAN, K.V., BOSTOCK, K.V., DUFFEY, S.S. 1998 Stimulation and Attenuation of Induced Resistance by Elicitors and Inhibitors of Chemical Induction in Tomato (Lycopersicon esculentum) Foliage. Entomologia Experimentalis et Applicata, 86, 267-279.

http://dx.doi.org/10.1046/j.1570-7458.1998.00289.x

THIPYAPONG, P., STOUT, M.J., ATTAJARUSIT, J. 2007. Functional Analysis of Polyphenol Oxidases by Antisense/Sense Technology. Molecules, 12, 15691595

http://dx.doi.org/10.3390/12081569

WU, J.C., XU, J.X., YUAN, Sh.Z., LIU, J.L., JIANG, Y.H., XU, J.F. 2001 Pesticide-induced susceptibility of rice to brown planthopper Nilaparvata Lugens. Entomologia Experimentalis et Applicata, 100, 119-126. http://dx.doi.org/10.1046/j.1570-7458.2001.00854.x

ZAGORCHEV, L., SEAL, Ch.E., KRANNER, I., ODJAKOVA, M. 2013. A Central Role for Thiols in Plant Tolerance to Abiotic Stress. International Journal of Molecular Sciences, 14, 7405-7432

http://dx.doi.org/10.3390/ijms14047405

ZHANG, J., KIRKHAM, M.B. 1994. Drought-Stress-Induced Changes in Activities of Superoxide Dismutase, Catalase, and Peroxidase in Wheat Species Plant and Cell Physiology, 35, 785-791 http://dx.doi.org/10.1111/j.1469-8137.1996.tb01856.x 